\title{
154. On the Relative Activities of Diaptomus chaffanjoni and Cyclops strenuus at Different Temperatures.
}

\author{
By Isamu HoRasawa. \\ Zoological Institute, College of Literature and Science, Tokyo.
}

(Comm. by A. OKA, M.I.A., Dec. 12, 1935.)

1.

Diaptomus chaffanjoni Richard and Cyclops strenuus Fisher are main components of plankton at Senshunen Pond in the compound of the Tokyo Literature and Science University; the former is abundant in summer and the latter in winter every year. ${ }^{1)}$

The author has made several experiments on these Copepoda. The present paper deals with the relative activities of these organisms at different temperatures.

As the standard of quantitative measurement of relative activity of the Copepoda, the author employed Pekarek's method of mittlere doppelseitige ${ }^{2)}$ Erstpassagezeit, which has been used in the study of Brownian movement of minute granules in the protoplasm.

The materials were kept about 40 minutes in the water of experimental temperature before the observation.

2.

The results of these experiments are shown in table 1 and Fig. 1.

TABLE 1.

\begin{tabular}{c|c|c|c}
\hline \multicolumn{2}{c|}{ D. chaffanjoni. } & \multicolumn{2}{|c}{ C. strenuus. } \\
\hline & $\begin{array}{c}\text { Seconds for 10 } \\
\text { crossing }\end{array}$ & Temp. & $\begin{array}{c}\text { Minutes for } 30 \\
\text { crossing }\end{array}$ \\
\hline & & & \\
\hline 8.2 & 270.5 & 3.5 & 3.7 \\
9.7 & 235.5 & 5.8 & 3.5 \\
12.3 & 189.7 & 8.2 & 2.7 \\
14.4 & 170.3 & 10.0 & 3.0 \\
16.7 & 192.4 & 11.0 & 2.8 \\
18.5 & 158.6 & 13.0 & 2.8 \\
20.0 & 117.3 & 15.5 & 1.8 \\
22.0 & 105.6 & 20.0 & 2.0 \\
24.6 & 89.0 & 21.5 & 1.7 \\
27.0 & 88.0 & & \\
29.0 & 85.3 & & \\
\hline
\end{tabular}

The temperature coefficients of these reactions have been calcu-

1) Horasawa, I. 1932. The relation between the periodicity of Plankton and the nature of the water in Sotobori and Senshun-ike Pond (in Japanese). Japanese Jour. limnol. Vol. 2, p. 29-43.

2) The parallel lines were at intervals of $9 \mathrm{~mm}$ at the first experiment and at the second were of $10 \mathrm{~mm}$. 
lated with the application of Bèlehládek's ${ }^{1)}$ formula $y=\frac{a}{x^{b}}$ as follows.

TABLE 2. Temperature coefficient (b).

\begin{tabular}{c|c|c|c|c}
\hline \multicolumn{3}{c|}{ Diaptomus chaffanjoni. } & \multicolumn{2}{c}{ Cyclops strenuus. } \\
\hline $\begin{array}{c}\text { range of } \\
\text { Temp. }\end{array}$ & XII 13-14, 34. & $\begin{array}{c}\text { Exp. } 2 . \\
\text { X 6, } 35 .\end{array}$ & $\begin{array}{c}\text { range of } \\
\text { Temp. }\end{array}$ & $\begin{array}{c}\text { Exp. 1. } \\
\text { XII 13-14, } 34 .\end{array}$ \\
$9-16^{\circ} \mathrm{C}$ & 0.56 & 0.70 & $3-9^{\circ} \mathrm{C}$ & 0.106 \\
$17-24^{\circ} \mathrm{C}$ & 2.39 & 2.27 & $10-21^{\circ} \mathrm{C}$ & 0.77 \\
\hline
\end{tabular}

These values of $b$ are coincident with other reactions of the two Copepoda, such as that of heart beat, contractile movement of alimentary canal etc. Those of Diaptomus chaffanjoni of Exp. 1 and 2 slightly differ in their values, probably due to the error of experiment and the seasonal difference of the time of experiments, as in the case of Lang, ${ }^{2)}$ Crozier and Stier $^{3)}$ etc.

The critical points of Diaptomus chaffanjoni are distributed as follows, namely, $8-10^{\circ} \mathrm{C}, 16-17^{\circ} \mathrm{C}$ and $24^{\circ} \mathrm{C}$ and

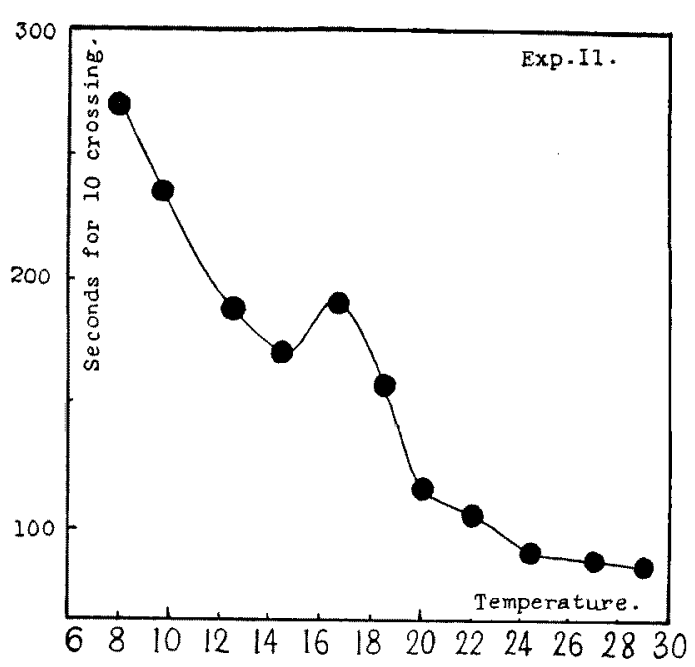

Fig. 1. The relative activity of Diaptomus chaffanjoni at different Temperatures. at the second one of these, that is, at $16-17^{\circ} \mathrm{C}$, the peculiar mode of

Log. $x$.

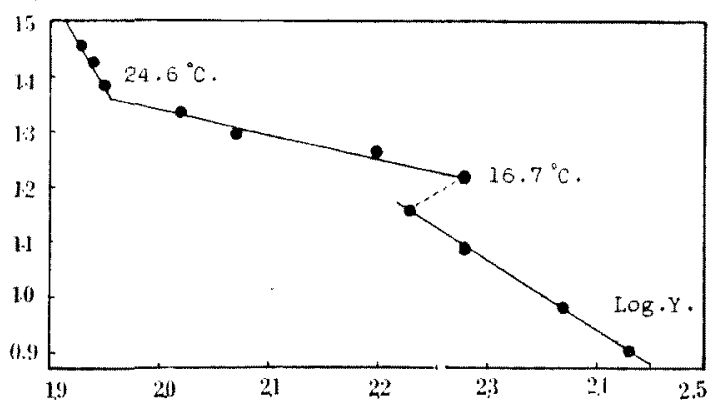

Fig. 2. The relative activity of Diaptomus chaffanjoni at different Temperatures. reaction has occurred as shown in Fig. 1. Such a sudden retardation of the biological processes may be due to the peculiarity of the colloidal state of protoplasm.

The temperature coefficients of Cyclops strenuus are lower than those of Diaptomus chaffanjoni, the critical point being $8-10^{\circ} \mathrm{C}$.

The above-mentioned critical temperature suggests

1) Bělehrádek, J. 1926. Influence of temperature on biological processes. Nature. Vol. 118, p. 117-118.

2) Lang, A. 1910. Über den Herzschlag von Helix pomata L. während des Winterschlafes. Festschr. z. 60. Geburtst., Rich. Hertwigs, 3, S. -A. (abter Kaniz. 1915).

3) Crozier, W. J. and Stier, T. B. 1925. Temperature characteristics for heart beat frequency in limax. Journ, Gen. Physiol. Vol. 7, p. 705-708. 


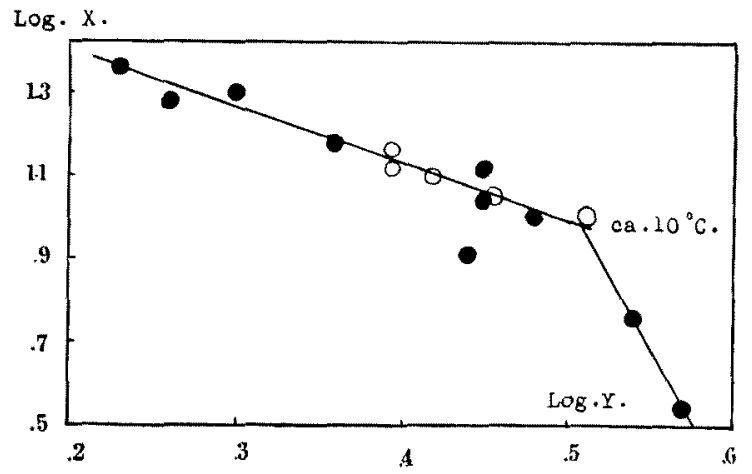

Fig. 3. The relative activity of Cycrops strenuus at different Temperatures. us the important significance of analysing the ecological habitudes of Diaptomus chaffanjoni and Cyclops strenuus in Senshunen Pond.

The Diaptomus chaffanjoni is one of the stenowarm water forms widely distributed in the Southwestern part of Japan and is plentiful in the pond aforementioned and actively propagates in the warmer season when the water temperature is above $16-17^{\circ} \mathrm{C}$, namely, above the peculiar critical temperature of Diaptomus and with the cooling of the pond water below this point, gradually decreases in number of individuals.

The periodicity of Cyclops strenuus is opposed to that of Diaptomus. It increases in number in the cold season and reaches the maximum number at the time when the water is cooled below the critical temperature of the present species, $8-10^{\circ} \mathrm{C}$. These relations are shown in Fig. 4 in the text.

As described above, the range of optimum temperature of Diaptomus is $17-24^{\circ} \mathrm{C}$ and that of Cyclops strenuus below $10^{\circ} \mathrm{C}$. In closing the author has much pleasure in tendering his thanks to Prof. Y. Okada for the valuable criticism.

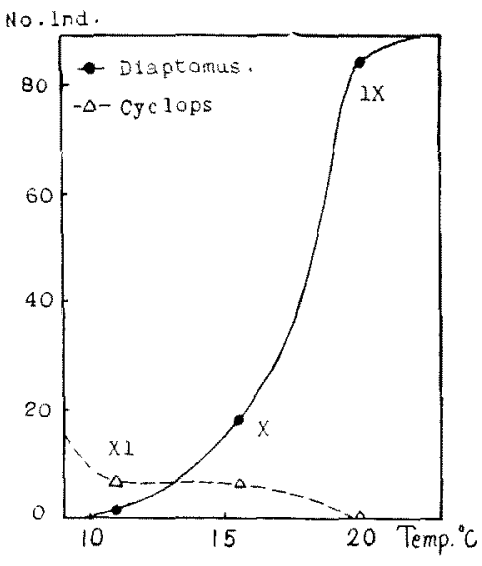

Fig. 4. The relation between the temperature and the periodicity of Diaptomus chaffanjoni and Cycrops strenuus. 